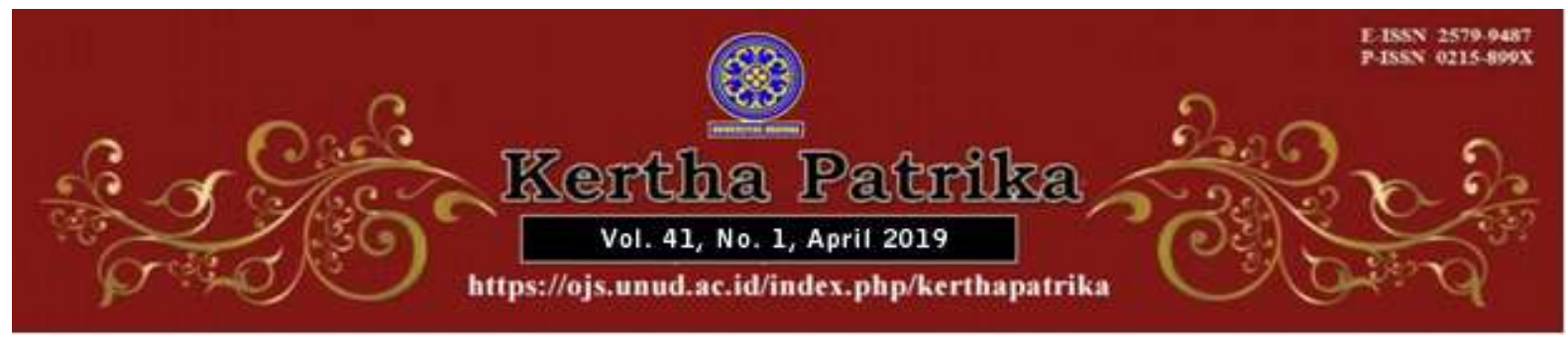

\title{
Tinjauan Yuridis Upaya Hukum Atas Putusan dan Penetapan Terhadap Pelanggaran Lalu Lintas
}

\section{Adji Prakoso ${ }^{1}$}

1Pengadilan Negeri Palangka Raya, E-mail: adji.prakoso7@gmail.com

\begin{tabular}{l}
\hline Info Artikel \\
\hline Masuk : 12 April 2019 \\
Diterima : 28 April 2019 \\
Terbit : 30 April 2019 \\
Keywords : \\
Infringement; Traffic; Legal \\
Effort; Determination; Verdict. \\
\\
Kata kunci: \\
Pelanggaran; Lalu Lintas; \\
Upaya Hukum; Penetapan; \\
Putusan.
\end{tabular}

\begin{abstract}
This article describes the mechanism of legal effort towards verdicts or determination of traffic infringement. It uses a normative research method along with quantitative approach. The research shows the need for further regulation regarding the flow of the process of the trial of resistance/objection to the verdict of independence deprivation for traffic infringement and the deadline for resolving the resistance/objection cases towards the verdict of independence deprivation for traffic infringement. Besides, there is a need legal effort mechanism for the criminal penalties determination of traffic infringement as control and maintain legal unity of all product decisions/judicial institution determination.
\end{abstract}

\section{Pendahuluan}

Dalam melaksanakan kehidupan bermasyarakat, berbangsa, dan bernegara, manusia tak bisa terlepas dari kewajiban melaksanakan hukum. Hal ini terkait dengan pengertian hukum sebagai himpunan petunjuk-petunjuk hayati (perintah-perintah dan larangan-larangan) yang mengatur tata tertib dalam suatu masyarakat. ${ }^{1}$ Hampir setiap bidang kehidupan sekarang ini diatur oleh peraturan-peraturan hukum. Melalui penormaan terhadap tingkah laku manusia ini hukum menelusuri hampir semua

1 Sumadi, A. F. (2015). Hukum dan Keadilan Sosial dalam Perspektif Hukum Ketatanegaraan. Jurnal Konstitusi, 12(4). 856-857, DOI: https://doi.org/10.31078/jk1249. 
bidang kehidupan manusia. Campur tangan hukum yang semakin meluas kedalam bidang kehidupan masyarakat menyebabkan masalah efektifitas penerapan hukum menjadi semakin penting. Oleh karena hukum mempunyai suatu fungsi dalam masyarakat.

Pemikiran tentang hukum dalam beberapa dasawarsa (decade) terakhir ini telah banyak berubah sebagai akibat daripada perubahan besar dalam masyarakat, teknologi dan tekanan-tekanan (pressures) yang disebabkan pertambahan penduduk. Konsepsi hukum sebagai sarana pembangunan sedikit banyak diilhami oleh teori tool of social engineering.

Pengembangan teoritis hukum sebagai alat pembaharuan masyarakat lebih luas jangkauannya dan ruang lingkupnya di Indonesia daripada di tempat kelahirannya sendiri. Penegakan hukum bukanlah penghambat pembangunan ekonomi, tetapi justru menjadi motor penggerak yang akan mengarahkan proses pembangunan ekonomi yang adil dan beradab. Penegakan hukum, akan memastikan terwujudnya keadilan ekonomi, persaingan sehat, dan pemerataan pembangunan di segala bidang. ${ }^{2}$

Perubahan sosial secara umum menampakan diri dalam bentuk perubahan yang menimbulkan akibat sosial sedemikian rupa sehingga terjadi dalam bentuk, susunan serta hubungan yang berbeda dari yang semua ada. ${ }^{3}$ Perubahan besar dalam kehidupan social masyarakat dan teknologi mempengaruhi perubahan tatanan hukum Indonesia. Salah satunya adalah kemajuan hukum untuk menyelesaikan permasalahan bidang lalu lintas dan angkutan jalan. Masalah lalu lintas merupakan masalah yang dihadapi oleh negara-negara maju dan berkembang seperti Indonesia. Namun di Indonesia permasalahan yang sering dijumpai pada masa sekarang menjadi lebih parah dan lebih besar dari tahun-tahun sebelumnya baik mencakup kecelakaan, kemacetan, polusi udara dan pelanggaran lalu lintas. ${ }^{4}$

Adapun dari beberapa masalah tersebut, masalah utama adalah kecelakaan lalu lintas. Dalam kurun waktu 10 tahun terakhir, kecelakaan lalu lintas yang terjadi di Indonesia telah merenggut korban jiwa rata-rata 10.000 per tahun. Hal mana menunjukan bahwa sekitar 332 orang meninggal dunia dari 1000 kecelakaan yang terjadi. Kecelakaan selain menimbulkan korban jiwa, juga menimbulkan kerugian secara finansial/materil. Kerugian tersebut di Indonesia diperkirakan mencapai 41,3 (empat puluh satu koma tiga) triliun rupiah. ${ }^{5}$

Adapun untuk menyelesaikan permasalahan hukum di bidang lalu lintas dan angkutan jalan telah dibentuk Undang-Undang Nomor 22 tahun 2009 tentang Lalu Lintas dan Angkutan Jalan. Dimana berdasarkan Pasal 3 Undang-Undang Nomor 22 tahun 2009 tentang Lalu Lintas dan Angkutan Jalan salah satu tujuan dibentuknya UU

2 Sukardi. (2016). Peran Penegakan Hukum Dalam Pembangunan Ekonomi. Jurnal Hukum dan Pembangunan, 46(4). 445, DOI: http://dx.doi.org/10.21143/ihp.vol46.no4.48.

3 Halim, F. (2015). Hukum dan Perubahan Sosial. Al Daulah: Jurnal Hukum Pidana dan Ketatanegaraan, 4(1). 109, DOI :https://doi.org/10.24252/ad.v4i1.,492.

4 Arif Budiarto dan Mahmudal. (2007). Rekayasa Lalu Lintas. UNS Press. h. 3.

5 Majalah Marka. (2004). Kecelakaan Lalu Lintas. Edisi XXV. h. 14. 
tersebut adalah terwujudnya penegakan hukum dan kepastian hukum bagi masyarakat.

Demi mewujukan penegakan hukum yang efektif, efisien dan memberikan kepastian hukum dalam penyelesaian pelanggaran lalu lintas, dimana Mahkamah Agung RI membuat terobosan hukum dengan menerbitkan Peraturan Mahkamah Agung RI Nomor 12 Tahun 2016 tentang Tata Cara Penyelesaian Pelanggaran Lalu Lintas. Terbitnya Perma dimaksud sebagaimana fungsi mengatur Mahkamah Agung RI untuk membuat peraturan lebih lanjut yang diperlukan bagi penyelenggaraan peradilan apabila terdapat hal-hal yang belum diatur dalam peraturan perundang-undangan sebagaimana Pasal 79 Undang-Undang Nomor 14 Tahun 1985 tentang Mahkamah Agung jo Undang-Undang Nomor 3 Tahun 2009 tentang Perubahan Kedua Atas Undang-Undang Nomor 14 Tahun 1985 tentang Mahkamah Agung, dikarenakan adanya perluasan jenis pelanggaran lalu lintas dalam Undang-Undang Nomor 22 tahun 2009 tentang Lalu Lintas dan Angkutan Jalan yang penyelesaiannya tidak diatur dalam Pasal 211 Undang-UndangNomor 8 Tahun 1981 tentang Hukum Acara Pidana (KUHAP).

Selain itu sebagai upaya menghapuskan praktik percaloan perkara tilang, dimana pelanggar tidak harus hadir di persidangan sebagaimana Pasal 4 Perma Nomor 12 Tahun 2016 tentang Tata Cara Penyelesaian Pelanggaran Lalu Lintas, terkecuali bagi individu yang mengajukan perlawanan terhadap putusan tentang perampasan kemerdekaan dapat mengajukan perlawanan pada hari sidang pembacaan putusan sebagaimana Pasal 7 Ayat 4 Perma Nomor 12 Tahun 2016 tentang Tata Cara Penyelesaian Pelanggaran Lalu Lintas.

Mantan Kepala Humas dan Biro Hukum Mahkamah Agung RI Ridwan Mansyur, Perma Nomor 12 Tahun 2016 tentang Tata Cara Penyelesaian Pelanggaran Lalu Lintas mengubah mekanisme sidang tilang agar proses penyelesaian lebih mudah, cepat dan sederhana (speedy trial). Pointer penting pelanggar tidak harus hadir di persidangan kecuali bagi individu yang mengajukan perlawanan terhadap putusan tentang perampasan kemerdekaan. Pelanggarnya cukup membayar hukuman denda tilang secara tunai atau elektronik kerekening kejaksaan melalui bank yang ditunjuk (Bank Rakyat Indonesia). Lalu, pengambilan barang bukti melalui jaksa selaku eksekutor di kejaksaan setempat dengan menunjukan bukti pembayaran denda. ${ }^{6}$

Namun Perma Nomor 12 Tahun 2016 tentang Tata Cara Penyelesaian Pelanggaran Lalu Lintas belum menjelaskan secara detail mekanisme penyelesaian perkara perlawanan (alur proses persidangan) terhadap keberatan putusan tentang perampasan kemerdekaan atas pelanggaran lalu lintas. Demikian pula Perma Nomor 12 Tahun 2016 tersebut belum menjelaskan mekanisme upaya hukum atas penetapan pidana denda pelanggaran lalu lintas sebagaimana dimaksud Pasal 2 Perma Nomor 12 Tahun 2016 tentang Tata Cara Penyelesaian Pelanggaran Lalu Lintas7.

6 Perma Perkara Tilang Terbit Ini Poin Yang Layak Anda Ketahui, https://www.hukumonline.com/berita/baca/lt585a7019e0a5d/perma-perkara-tilangterbit--ini-poin-yang-layak-anda-ketahui, diakses 21 Desember 2016.

7 Peraturan Mahkamah Agung Nomor 12 Tahun 2016 tentang Tata Cara Penyelesaian Pelanggaran Lalu Lintas, Pasal 4 


\section{Metode Penelitian}

Metode penelitian yang digunakan adalah penelitian normatif yang mengkaji dari berbagai aspek seperti teori, filosofi, perbandingan, struktur/komposisi, konsisten, penjelasan umum dan tiap pasal dalam peraturan perundang-undangan maupun literatur yang berkaitan dengan permasalahan yang diteliti seperti buku, jurnal, majalah, materi simposium dan pemberitaan online.

Adapun penelitian yang dilakukan penulis,menggunakan pendekatan secara kualitatif dan mempunyai sifat deskriptif analisis yang memberikan gambaran secara filosofis, teoritis dan kondisi praktik upaya hukum atas putusan dan penetapan terhadap pelanggaran lalu lintas yang diatur dalam Perma Nomor 12 Tahun 2016 tentang Tata Cara Penyelesaian Pelanggaran Lalu Lintas.

\section{Hasil dan Pembahasan}

\subsection{Kewenangan Mengadili Pelanggaran Lalu Lintas Dalam Perma Nomor 12 Tahun 2016}

Pembaharuan perundang-undangan ini mutlak perlu dilakukan dan harus mendapat prioritas pertama, disebabkan sampai sekarang hukum tata negara kita yang berdasarkan kepada Pancasila dan Undang-Undang Dasar 1945 belum pernah diadakan perencanaan dan pembaharuan perundang-undangan di Indonesia secara efektif dan memadai, melainkan disesuaikan menurut situasi dan kondisi tanpa adanya daftar skala prioritas. ${ }^{8}$

Pembaharuan dalam perundang-undangan pidana ataupun prosedur yang dapat dilaksanakan pada waktu sekarang ataupun untuk masa yang akan datang, dan yang memungkinkan pelaksanaan dari Hukum Pidana yang dikodifikasikan ataupun yang tidak menjadikan Hukum Pidana dan acaranya tertulis maupun hukum Penitentiair sebagai sumber utama bagi Pengadilan, Kejaksaan dan Kepolisian.

Eksistensi peranan Peraturan Mahkamah Agung dalam memenuhi kebutuhan peradilan di Indonesia dapatlah terlihat dari Himpunan Peraturan Mahkamah Agung yang dikeluarkan dari tahun ke tahun. Keberadaan peraturan perundang-undangan yang terus mengikuti perkembangan dunia peradilan yang ada haruslah menjadi penopang dalam menjalankan sistem peradilan yang baik. ${ }^{9}$

Perma Nomor 12 Tahun 2016 tentang Tata Cara Penyelesaian Pelanggaran Lalu Lintas merupakan sumber utama penyelesaian pelanggaran lalu lintas yang memberikan kemudahan bagi para pencari keadilan dan khususnya pelanggar lalu lintas. Berdasarkan Pasal 2 jo 4 Perma Nomor 12 Tahun 2016 tentang Tata Cara Penyelesaian

8 Bahar, U. (1984). Pembaharuan Perundang-Undangan Di Indonesia. Jurnal Hukum $\mathcal{E}$ Pembangunan, 14(1).51, DOI: http://dx.doi.org/10.21143/jhp.vol14.no1.1010.

9 Tamin, B. E. D. (2019). Tinjauan Yuridis Terhadap Kedudukan Peraturan Mahkamah Agung (Perma) Dalam Hierarki Peraturan Perundang-Undangan Di Indonesia. Lex Administratum, 6(3).119. 
Pelanggaran Lalu Lintas hamper keseluruhan jenis pelanggaran yang terdapat dalam Undang-Undang Nomor 22 Tahun 2009 tentang Lalu Lintas dan Angkutan Jalan diselesaikan melalui persidangan yang efektif dan efisien tanpa perlu hadirnya Pelanggar. ${ }^{10}$

Adapun pengecualian pelanggaran lalu lintas seperti perbuatan yang mengakibatkan ganguan fisik jalan atau perlengkapan jalan (Pasal 274 Ayat 1 dan 2 UU Lalu Lintas dan Jalan), perbuatan yang mengakibatkan gangguan rambu lalu lintas, marka jalan, fasilitas pejalan kaki dan pengaman pengguna jalan (Pasal 275 Ayat 1 UU Lalu Lintas dan Jalan), pihak penyedia jasa angkutan umum yang tidak bertanggung jawab atas kerugian penumpang dan/atau pengirim barang (pasal 309 Ayat 1 UU Lalu Lintas dan Jalan) dan Perusahaan umum yang tidak mengasuransikan kecelakaan pengemudi dan penumpangnya (Pasal 313 UU Lalu Lintas dan Jalan) yang penyelesaiannya bukan kewenangan Perma dimaksud sesuai Pasal 2 Nomor 12 Tahun 2016 Tata Cara Penyelesaian Pelanggaran Lalu Lintas. ${ }^{11}$

\subsection{Prinsip Upaya Hukum}

Upaya Hukum atau rechtsmiddel itu adalah upaya yang diberikan oleh hukum (dalam arti sempit undang-undang) kepada seseorang untuk dalam suatu hal tertentu melawan putusan hakim.12 Upaya hukum merupakan sarana untuk melaksanakan hukumya itu hak terpidana atau jaksa penuntut umum untuk tidak menerima penetapan atau putusan pengadilan, karena tidak merasa puas dengan penetapan atau putusan tersebut.

Upaya hukum adalah upaya yang diberikan oleh undang-undang kepada seseorang atau badan hukum untuk dalam hal tertentu melawan putusan hakim. Dalam hal ini berkaitan dengan hak asasi manusia yang mengajukan padahal bagi seseorang yang dikenai oleh putusan hakim tersebut ${ }^{13}$.Adapun maksud dari upaya hukum itu sendiri pada pokoknya adalah untuk memperbaiki kesalahan yang dibuat oleh instansi yang sebelumnya dan kesatuan dalam peradilan. ${ }^{14}$ Dengan adanya upaya hukum ini ada jaminan bagi terdakwa ataupun masyarakat bahwa peradilan, baik menurut fakta maupun hukum adalah benar dan sejauh mungkin dari seragam. ${ }^{15}$ Adapun maksud dari upaya hukum menurut pandangan doktrina pada pokoknya agar: ${ }^{16}$

1. Diperoleh kesatuan dan kepastian dalam hal menjalankan peradilan (operasiyustisie)

10 Perma Nomor 12 Tahun 2016 tentang Tata Cara Penyelesaian Pelanggaran Lalu Lintas. Pasal 2

11 Ibid.

12 Oeripkartawinata, I. (1981). Upaya-Upaya Hukum Yang Dapat Digunakan Oleh Pencari Keadilan Menurut Hukum Acara Perdata Di Indonesia. Jurnal Hukum \& Pembangunan, 11(5).443, DOI: http://dx.doi.org/10.21143/ihp.vol11.n5.

13 Putra Halomoan HSB. (2015). Tinjauan Yuridis Tentang Upaya-Upaya Hukum, Yurisprudentia: Jurnal Hukum Dan Ekonomi, 1(1).43.

14 Lilik Mulyadi. (2007). Hukum Acara Pidana. Bandung: Citra Aditya Bakti.h.234.

15 (1976).Pedoman Pelaksanaan KUHAP. Jakarta ; Erlangga. h. 159.

16 Djoko Prakoso. (1987).Upaya Hukum Yang Diatur Dalam KUHAP.Aksara Persada.h.53. 
2. Melindungi tersangka terhadap tindakan-tindakan yang bersifat sewenangwenang dari hakim;

3. Memperbaiki kealpaan-kealpaan dalam menjalankan peradilan;

4. Usaha dari para pihak, baik terdakwa maupun jaksa memberikan keteranganketerangan baru (novum).

\subsection{Perbandingan Bentuk Upaya Hukum Perlawanan}

Bahwa Perma Nomor 12 Tahun 2016 belum mengatur lebih lanjut alur proses persidangan upaya hukum perlawanan dan tenggang waktu penyelesaian perlawanan terhadap keberatan putusan tentang perampasan kemerdekaan atas pelanggaran lalu lintas sebagaimana dimaksud Pasal 7 Ayat 4 Perma Nomor 12 Tahun 2016 tentang Tata Cara Penyelesaian Pelanggaran Lalu Lintas. Dengan demikian penulis melakukan perbandingan bentuk upaya hukum perlawanan dalam penyelesaian perkara pidana lainnya.

Bahwa baik penetapan maupun putusan sela atau tussen-vonnis dapat diajukan perlawanan (verzet) kepada pengadilan tinggi melalui pengadilan negeri yang menerima pelimpahan perkara/memutus perkara sebagaimana ketentuan Pasal 148 KUHAP yaitu ketika Ketua Pengadilan Negeri menerima pelimpahan perkara, kemudian mengeluarkan surat penetapan atau penetapan.

Jadi dalam hal ini perlawanan sebelum perkara disidangkan ${ }^{17}$. Terhadap penetapan melalui ketentuan Pasal 148 KUHAP apabila penuntut umum berkeberatan, penuntut umum dapat mengajukan perlawanan verzet kepada Pengadilan Tinggi yang bersangkutan dalam waktu tujuh hari setelah penetapan diterima. Tenggang waktu perlawanan selama tujuh hari ini bersifat limitatif oleh karena tidak dipenuhi tenggang waktu menyebabkan batalnya perlawanan.

Kemudian pelawanan (verzet) penuntut umum ini disampaikan kepada Ketua Pengadilan Negeri lalu dicatat dalam buku daftar panitera dan dalam waktu. ${ }^{18}$ Pada asasnya, verzet hanya dapat dilakukan terhadap perkara yang dilimpahkan ke pengadilan dan belum ditunjuk majelis hakim yang akan menanganinya, putusan pengadilan negeri yang belum memeriksa 'pokok perkaranya' 19 .

Setelah pengadilan tinggi menerima berkas perkara perlawanan, dalam tenggang waktu empat belas hari pengadilan tinggi harus memutus dengan penetapan perlawanan tersebut yang dapat menguatkan atau menolak perlawanan itu (Pasal 149 Ayat 2 KUHAP). Apabila Pengadilan Tinggi menguatkan perlawanan dari penuntut umum, dengan surat penetapan atau penetapan pengadilan negeri diperintahkan untuk menyidangkan perkara itu (Pasal 149 Ayat (3) KUHAP). Begitu pun sebaliknya jika Pengadilan Tinggi menguatkan pendapat pengadilan negeri, pengadilan tinggi mengirimkan berkas perkara pidana tersebut kepada pengadilan negeri yang bersangkutan dan tembusan penetapan pengadilan tinggi disampaikan kepada penuntut umum (Pasal 149 Ayat (4) dan (5) KUHAP). ${ }^{20}$

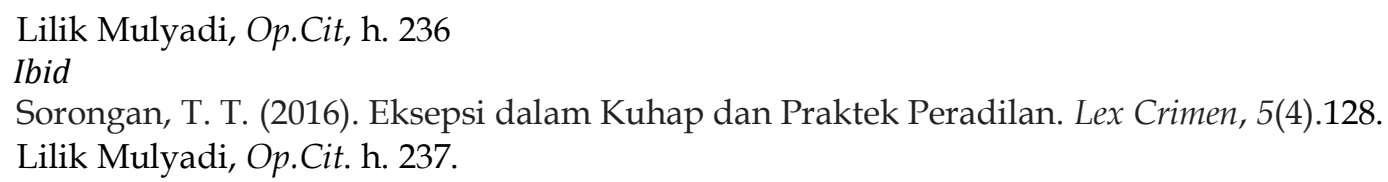


Berdasarkan ketentuan Pasal 156 Ayat (3) s.d. 6 KUHAP, perlawanan (verzet) ini dapat diajukan oleh penuntut umum, terdakwa atau penasehat hukum ke Pengadilan Tinggi melalui Pengadilan Negeri yang bersangkutan. Perlawanan dapat diajukan pelawan di kepaniteraan Pengadilan Negeri yang memutus perkara dan dicatat dalam buku panitera. Pada praktik yang tengah berjalan, biasanya pelawan mengajukan memori perlawanan sedangkan pihak lainnya mengajukan kontra memori atas memori dari perlawanan. Mengenai tenggang waktu mengajukan perlawanan sesuai Pasal 156 Ayat 3 KUHAP tidak ditentukan secara eksplisit. Penyebutan waktu empat belashari pada Pasal 156 Ayat 4 KUHAP bukanlah dimaksudkan sebaga tenggang waktu untuk mengajukan perlawanan, melainkan merupakan tenggang waktu pengadilan tinggi apabila telah menerima berkas perkara dari pengadilan negeri untuk memutus perkara tersebut dengan surat penetapnnya. Setelah keputusan (putusan sela) atas keberatan dari Terdakwa atau penasehat hukum dibenarkan oleh majelis hakim, penuntut umum dapat menentukan sikap yang berupa penuntut umum tidak mengajukan perlawanan atau penuntut umum mengajukan perlawanan. ${ }^{21}$

Sebelum adanya Perma Nomor 12 Tahun 2016 tentang Tata Cara Penyelesaian Pelanggaran Lalu Lintas, dimana pelanggaran lalu lintas tertentu diperiksa menggunakan hukum acara pemeriksaan lalu lintas di KUHAP sebagaimana Pasal 211 Undang-Undang Nomor 8 Tahun 1981 tentang Hukum Acara Pidana. ${ }^{22}$ Adapun perkara pelanggaran lalu lintas tertentu berdasarkan penjelasan Pasal 211 UndangUndang Nomor 8 Tahun 1981 tentang Hukum Acara Pidana sebagai berikut :

a. Merusak jalan atau menggunakan jalan yang bahayakan keselamatan;

b. Mengemudikan kendaraan bermotor tanpa SIM, STNK, KIR atau masa berlakunya sudah daluwarsa;

c. Membiarkan atau memperkenankan orang tidak memiliki SIM mengemudikan kendaraan bermotornya;

d. Tidak memenuhi ketentuan perlengkapan, penomoran, penerangan atau peralatan kendaraan bermotor;

e. Menggunakan plat nomor kendaraan bermotor yang tidaksah;

f. Pelanggaran terhadap petugas pengatur lalu lintas atau rambu lalu lintas;

g. Pelanggaran beban muatan atau cara menaikan penumpang;

h. Pelanggaran terhadap izin trayek.

Jadi dahulu putusan pelanggaran lalu lintas sebagaimana dimaksud Pasal 211 KUHAP, yang mana dijatuhkan di luar hadirnya Terdakwa, terdakwa dapat mengajukan perlawanan, namun tidak terhadap semua putusan verstek dapat diajukan perlawanan. Perlawanan atau verzet atas putusan verstekhanya dapat dilakukan atas putusan yang tertentu saja. Perlawanan diajukan ke Pengadilan dan verzet hanya dilakukan atas perampasan kemerdekaan. ${ }^{23}$

Tenggang waktu mengajukan perlawanan yang diatur dalam Pasal 214 Ayat (4) KUHAP adalah 7 (tujuh) hari, terhitung sejak tanggal pemberitahuan putusan kepada terpidana. Berarti jika terpidana hendak mempergunakan perlawanan terhadap

Ibid. h. 237-238

Undang-Undang Nomor 8 Tahun 1981 tentang Hukum Acara Pidana

M Yahya Harahap. (2016).Pembahasan Permasalahan dan Penerapan KUHAP. Jakarta; Sinar

Grafika, h. 439. 
putusan yang dijatuhkan di luar hadirnya, hanya dapat dilakukan atau diajukan selama dalam tenggang waktu 7 (tujuh) hari terhitung sejak putusan diberitahukan penyidik kepadanya. Apabila tenggang waktu tersebut lewat, dengan sendirinya gugur hak terpidana mengajukan perlawanan. ${ }^{24}$

\subsection{Upaya Hukum Hak Pelanggar Lalu Lintas/Terdakwa Perkara Lain}

Bahwa belum ada ketentuan yang mengatur upaya hukum terhadap penetapan pidana denda pelanggaran lalu lintas dalam Perma Nomor 12 Tahun 2016 tentang Tata Tata Cara Penyelesaian Pelanggaran Lalu Lintas. Sedangkan prinsipnya seluruh putusan atau penetapan pemidanaan dapat diajukan upaya hukum banding terhadap putusan/penetapan tingkat pertama kecuali putusan bebas sebagaimana Pasal 67 KUHAP. Sedangkan Mahkamah Agung RI hanya melarang upaya hukum kasasi terhadap perkara pidanapenjara paling lama satu tahun/denda sesuai Pasal 45A Ayat 2 Undang-Undang Nomor 5 Tahun 2004 tentang Perubahan Atas Undang-Undang Nomor 14 Tahun 1985 tentang Mahkamah Agung25 jo Undang-Undang Nomor 3 Tahun 2009 tentang Perubahan Kedua Atas Undang-Undang Nomor 14 Tahun 1985 tentang Mahkamah Agung. ${ }^{26}$

\section{Kesimpulan}

Bahwa perlunya pengaturan lebih lanjut mengenai alur proses persidangan perlawanan/keberatan terhadap putusan perampasan kemerdekaan atas pelanggaran lalu lintas dan tenggang waktu penyelesaian perkara perlawanan/keberatan terhadap putusan perampasan kemerdekaan atas pelanggaran lalu lintas. Pengaturan lebih lanjut alur proses persidangan perlawanan dan tenggang waktu penyelesaian perlawanan terhadap putusan perampasan kemerdekaan atas pelanggaran lalu lintas dimaksud, untuk memberikan kepastian hukum dan menjamin keterbukaan informasi layanan pengadilan.

Demikian juga diperlukan adanya mekanisme upaya hukum terhadap penetapan pidana denda pelanggaran lalu lintas. Adanya mekanisme upaya hukum atas penetapan pidana denda pelanggaran lalu lintas sebagai wahana kontrol dan menjaga kesatuan hukum seluruh produk putusan/penetapan yang dikeluarkan lembaga peradilan.

\section{DAFTAR PUSTAKA}

\section{Buku}

Budiarto, A. \& Mahmudal. (2007). Rekayasa Lalu Lintas:UNS Press.

Prakoso, D. (1987). Upaya Hukum Yang Di Atur Dalam KUHAP: Aksara Persada.

\footnotetext{
24 Ibid.

${ }^{25}$ Lihat Pasal 45A Undang-Undang Nomor 5 Tahun 2004 tentang Perubahan Atas Undang-

Undang Nomor 14 Tahun 1985 tentang Mahkamah Agung.

${ }^{26}$ Lihat Undang-Undang Nomor 3 Tahun 2009 tentang Perubahan Kedua Atas Undang-Undang

Nomor 14 Tahun 1985 tentang Mahkamah Agung.
} 
Harahap, M. Y. (2016).Pembahasan Permasalahan dan Penerapan KUHAP, Sinar Grafika: Jakarta.

Mulyadi, L. (2007) Hukum Acara Pidana, Citra Aditya Bakti: Bandung.

Pedoman Pelaksanaan KUHAP, (1976). Erlangga: Jakarta.

\section{Jurnal dan Majalah}

Bahar, U. (1984). Pembaharuan Perundang-Undangan Di Indonesia. Jurnal Hukum $\mathcal{E}$ Pembangunan, 14(1).51, DOI: http://dx.doi.org/10.21143/jhp.vol14.no1.1010.

Halim, F. (2015). Hukum dan Perubahan Sosial. Al Daulah: Jurnal Hukum Pidana dan Ketatanegaraan, 4(1).109, DOI: https://doi.org/10.24252/ad.v4i1.1492.

Oeripkartawinata, I. (1981). Upaya-Upaya Hukum Yang Dapat Digunakan Oleh Pencari Keadilan Menurut Hukum Acara Perdata Di Indonesia. Jurnal Hukum dan Pembangunan, 11(5).443, DOI: http://dx.doi.org/10.21143/jhp.vol11.n5.

Putra Halomoan HSB. (2015). Tinjauan Yuridis Tentang Upaya-Upaya Hukum, Yurisprudentia: Jurnal Hukum Dan Ekonomi, 1(1).43.

Sukardi. (2016). Peran Penegakan Hukum Dalam Pembangunan Ekonomi. Jurnal Hukum dan Pembangunan, 46(4).445, DOI: http://dx.doi.org/10.21143/jhp.vol46.no4.48.

Sumadi, A. F. (2015). Hukum dan Keadilan Sosial dalam Perspektif Hukum Ketatanegaraan. Jurnal Konstitusi, 12(4).856-857,

DOI :https://doi.org/10.31078/jk1249.

Tamin, B. E. D. (2019). Tinjauan Yuridis Terhadap Kedudukan Peraturan Mahkamah Agung (Perma) Dalam Hierarki Peraturan Perundang-Undangan Di Indonesia. Lex Administratum, 6(3).119.

Majalah Marka. (2004). Kecelakaan Lalu Lintas. Edisi XXV.

\section{Peraturan Perundang-Undangan}

Undang-Undang Nomor 22 Tahun 2009 tentang Lalu Lintas dan Angkutan Jalan, Lembaran Negara Republik Indonesia Tahun 2009 Nomor 96.

Undang-Undang Nomor 8 Tahun 1981 tentang Hukum Acara Pidana, Lembaran Negara Republik Indonesia Tahun 1981 Nomor 76.

Undang-Undang Nomor 14 Tahun 1985 tentang Mahkamah Agung, Lembaran Negara Republik Indonesia Tahun 1985 Nomor 73. 
Undang-Undang Nomor 5 Tahun 2004 tentang Perubahan Atas Undang-Undang Nomor 14 Tahun 1985 tentang Mahkamah Agung, Lembaran Negara Republik Indonesia Tahun 2004 Nomor 9.

Undang-Undang Nomor 3 Tahun 2009 tentang Perubahan Kedua Atas UndangUndang Nomor 14 Tahun 1985 tentang Mahkamah Agung, Lembaran Negara Republik Indonesia Tahun 2009 Nomor 3.

Peraturan Mahkamah Agung Nomor 12 Tahun 2016 tentang Tata Cara Penyelesaian Pelanggaran Lalu Lintas, Berita Negara Republik Indonesia Tahun 2016 Nomor 1921.

\section{Internet}

Perma Perkara Tilang Terbit Ini Poin Yang Layak Anda Ketahui, https://www.hukumonline.com/berita/baca/1t585a7019e0a5d/perma-perkaratilang-terbit--ini-poin-yang-layak-anda-ketahui, diakses 21 Desember 2016. 